\title{
ELEMENTE DE ANTROPOLOGIE PRENATALĂ ÎN TEOLOGIA CREȘTINĂ A SECOLULUI AL II-LEA
}

\section{Petru CeRnAT*}

\begin{abstract}
Elements of prenatal anthropology in Christian theology of the second century ${ }^{1}$. The second Christian century is a time when the Church, through its theology, had to guide the communities founded by the Apostles, to defend itself against the accusations of the Romans and to combat the heresies that had already arisen among its believers. This context encourages the appearance of the writings of the Apostolic Fathers, the apologists and the polemic theology. One of the characteristic themes not only of the theology of this century, but always, is of the anthropology. The present paper aims to analyze how Church writers transposed "in the language" of their contemporaries the Bible teaching about man and his place in creation, with the emphasis on "prenatal man". We will find out if the Fathers of the Church were interested in human life in the womb, and if the answer is yes, we will try to answer the question: How did the Church Fathers speak for the first time about the human embryo? Here are other questions to be clarified: the theology of the Fathers was understood by the society of their time?
\end{abstract}

Keywords: embryo, abortion, second century, The Didache, prenatal anthropology.

\section{Introducere}

Conceptualizarea metafizică a omului prenatal, creionată de autorii creștini din secolul al II-lea, a fost strâns legată de intuițiile izvorâte din Scripturile ebraice și din Noul Testament. Și spunem intuiții, întrucât

* PhD Student, Faculty of Orthodox Theology at „Alexandru Ioan Cuza” University, Iaşi, Romania.

${ }^{1}$ Studiu redactat sub îndrumarea Pr. Prof. Univ. Dr. Gheorghe Popa, care şi-a exprimat acordul pentru publicare. 
Sfânta Scriptură nu cuprinde învățături explicite cu privire la avortul voluntar sau statutul embrionului uman. Primii creștini şi evreii se distingeau de majoritatea altor religii din lumea greco-romană și prin faptul că îsi întemeiau preceptele morale pe autoritatea Scripturii. În contrast, cercetarea istorică arată că religiile păgâne din antichitate tind să promoveze un fundament umanist al eticii, mai degrabă decât unul strict teist: „Nu există nicio autoritate supranaturală în afara acestei lumi care să dețină adevărul absolut și să-l transmită oamenilor prin intermediul unei cărți sfinte sau a învățăturilor unui om sfânt"'2. Influențați de acest fapt, greco-romanii au putut, într-o oarecare măsură, să îşi adapteze concepțiile despre copilul nenăscut în funcție de nevoile lor practice și emoționale individuale, precum și de perspectivele contextelor lor socio-culturale . $^{3}$.

Studiul de față își propune să analizeze cum se naște, în Tradiția creștină, reflecția despre omul prenatal și statutul său, ca prim pas în alcătuirea unei viziuni coerente cu privire la această problematică. În acest sens, vom analiza trei texte aparținând Părinţilor Apostolici: Didahia sau Învăţătura celor doisprezece Apostoli, Epistola lui Barnaba şi, într-o mai mică măsură, Epistola către Diognet, care se referă la interzicerea avortului, o problemă conexă cu cea a statutului embrionului sau fătului.

\section{Avortul și expunerea nou-născuților la Părinții Apostolici}

Eugenia antică a început în familie. De la naștere, fiecare nounăscut era prezentat tatălui, care îl accepta sau decidea să-1 expună fiarelor sălbatice. Această alegere, care avea loc în Grecia în timpul unei ceremonii sacre, a fost perfect legală. Legile diferitelor orașe au acordat lui pater familias dreptul de viață sau de moarte asupra copiilor săi în caz de malformații. Așa a fost, de asemenea, cazul şi în Roma ${ }^{4}$.

Confruntați cu această situație, Părinții Apostolici au creionat o atitudine etică, impunând interzicerea avortului și a expunerii nou-

2 Konstantinos KAPPARIS, Abortion in the Ancient World, London, Duckworth Academic, 2002, p. 197.

3 Julian BARR, Tertulian and the Unborn Child. Christian and Pagan Attitudes in Historical Perspective, London and New York, Routledge, 2017, p. 73.

${ }^{4}$ Philippe CASPAR, L'embryon au II ème siecle, Paris, L'Harmattan, 2002, p. 42. 
născuților. Astfel, Didahia sau Învățătura celor doisprezece Apostoli face referire la aceste două practici în două rânduri. De remarcat contextul în care se găsesc aceste afirmații. Este vorba despre cele două căi, calea vieții și calea morții. Această viziune a fost susținută de o conceptualizare a moralei ca fiind o alegere continuă între bine și rău. Alegerile bune i-au condus pe creștini pe calea luminii către viața veșnică. În schimb, alegerile rele i-au condus pe calea întunericului spre o condamnare eternă. Această organizare nu este lipsită de interes. Oricine recurge la avort sau la expunere se află pe calea pierzării sau a morții. Aceasta este o problemă morală centrală. În tratarea problemei, autorul procedează în două etape. În primul rând, el trasează o interdicție, apoi o fundamentează.

a) Interdicția este alcătuită destul de clar:

„Nu veți ucide, nu veți comite adulter, nu veți săvârși acte de pederastie, nu veți comite desfrânare, nu veți fura, nu veți practica vrăjitoria, nu veți ucide prin otrăvire, nu veți ucide un copil prin avort și

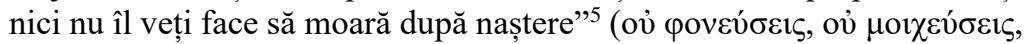

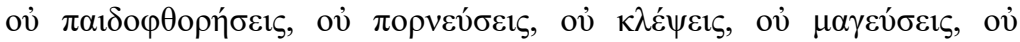

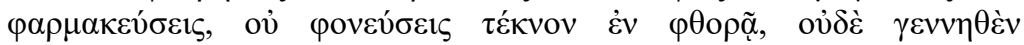
$\dot{\alpha} \pi \mathrm{O} \tau \varepsilon v \varepsilon \tilde{\varepsilon} \varsigma)^{6}$.

Am preferat traducerea lui „ov̉ $\varphi \alpha \rho \mu \alpha \kappa \varepsilon v ́ \sigma \varepsilon ı \varsigma ”$ prin ,, a ucide prin otrăvire”, cu toate că sensul lui inițial era cel de ,a practica magia/vrăjitoria". Acest verb, în perioada clasică și elenistică, uneori înseamnă ,a administra un medicament”, alteori ,a administra otravă”. De altfel, și Jurământul lui Hipocrate folosește substantivul derivat

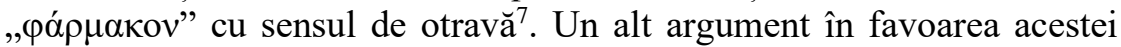
alegeri este prezența în aceeași frază a două verbe care par a desemna

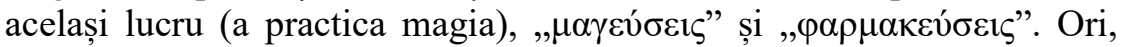
contextul ne permite să diferențiem între cele două, cel din urmă referindu-se la curmarea unei vieți prin administrarea de otravă, desemnând alături de celelalte două verbe care urmează după el,

5 Traducere proprie din greaca veche.

${ }^{6}$ The Teaching Of The Twelve Apostles, II, 2, translation by Philip Schaff, coll. AnteNicene Fathers, vol. 7, Massachusetts, Hendrickson Publishers, 1995, p. 377.

${ }^{7}$ Pentru o analiză amplă a textului Jurământului, vezi: Diego GrACIA, Fundamentos de bioética, Madrid, Editorial Triacastela, 2008, p. 45-71. 


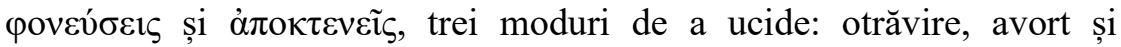
abandonare la naștere.

Dacă traducerea propusă este corectă, atunci putem fi de acord cu P. Caspar, care observă că Didahia interzice în aceeași propoziție și eutanasia (,nu vei ucide prin otrăvire”) și avortul (,nu vei ucide prin avort"), iar împreună cu Jurământul lui Hipocrate reprezintă singurele texte antice care condamnă în aceeași formulă ambele practici ${ }^{8}$.

Un alt element important de subliniat este echivalența pe care pare să ne-o transmită textul Didahiei între avort și expunerea nou-născuților,

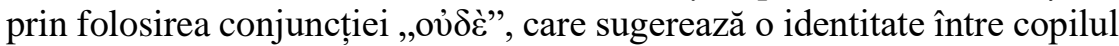
nenăscut și cel de curând născut. Mai exact, punerea împreună a acestor două practici demonstrează că autorul le consideră cel puțin acte similare, dacă nu identice 9 . Ar fi un pic forțat să vorbim despre distingerea etapelor de dezvoltare intrauterină, dar să reținem pentru discuția noastră că Didahia folosește și pentru copilul nenăscut și pentru cel născut acelaşi

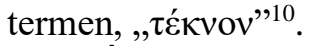

Însă cel mai important principiu care se referă la atitudinea morală față de omul prenatal derivă din contextul în care este rostită această interdicție: este vorba de punerea în practică a poruncii ,iubește pe aproapele tău ca pe tine însuți” (Mc. 12, 31). Didahia începe cu afirmarea existenței celor două căi, a vieții și a morții, apoi definește calea vieții ca fiind: iubirea lui Dumnezeu-Creatorul, iubirea aproapelui și regula de aur a moralei: „toate câte le voiești să nu ți se facă ție, nu le fă și tu altora” $\left(\right.$ Mt. 7, 12) ${ }^{11}$. Apoi urmează explicitarea practică a „definiției” de mai sus, printre care se cuprinde interzicerea avortului. Altfel spus, unul dintre modurile creștine de punere în practică a poruncii ,iubește-l pe aproapele tău ca pe tine însuți” este a refuza să faci avort. Astfel, autorul leagă întrun mod inedit conceptul de ,iubire-agape" de fetus, interpretând accentul pus de Iisus pe compasiune ca un îndemn pentru protejarea copilului în pântece ${ }^{12}$.

${ }^{8}$ P. CASPAR, L'embryon au II'me siecle, p. 30.

${ }^{9}$ J. BARR, Tertulian and the Unborn Child..., p. 83.

${ }^{10}$ The Teaching Of The Twelve Apostles, V, 2, trad. cit., p. 379.

${ }^{11}$ Didahia sau Invățătură a celor doisprezece Apostoli, I, 2, trad. Dumitru Fecioru, în: P.S.B. Vol. 1, București, EIBMBOR, 1979, p. 25.

12 J. BARR, Tertulian and the Unborn Child..., p. 82. 
Compasiunea sau filantropia are ca fundament teologic învăţătura că omul este chip al lui Dumnezeu, imago Dei în expresia latină. Locul clasic unde se găsește această învăţătură este Fac. 1, 26-27: „Şi a zis Dumnezeu: «Să facem om după chipul şi după asemănarea Noastră, ca să stăpânească peştii mării, păsările cerului, animalele domestice, toate vietăţile ce se târăsc pe pământ şi tot pământul!» Şi a făcut Dumnezeu pe om după chipul Său; după chipul lui Dumnezeu l-a făcut; a făcut bărbat şi femeie”. Credința că chipul lui Dumnezeu din om are implicații în protejarea vieții umane este sugerată de textul din Fac. 9, 6: „De va vărsa cineva sânge omenesc, sângele aceluia de mână de om se va vărsa, căci Dumnezeu a făcut pe om

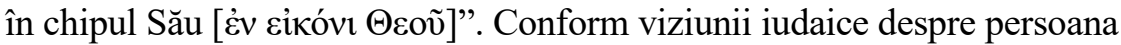
umană, aceasta din urmă este privită ca o unitate, mai degrabă decât în termeni dualiști. Există două elemente în natura unei persoane, sufletul (nephesh) și carnea (basar) sau trupul. Sufletul nu a fost făcut să existe în afară de trup. Distrugerea trupului înseamnă distrugerea personalităţii umane și, de aceea, reprezintă o atentare a demnității lui Iahve, a Cărui imagine (și, prin urmare, valoare) oamenii o poartă $\breve{a}^{13}$.

Această învăţătură (imago Dei) este moștenită de Noul Testament, care îi imprimă un nou accent, soteriologic și eshatologic: este preocupat de mântuirea și destinul final al umanității căzute. În această privință, doctrina Întrupării reprezintă contribuția majoră a Noului Testament la

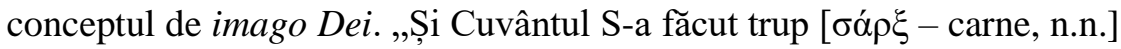
și S-a sălăşluit între noi și am văzut slava Lui” (In. 1, 14). Acest Cuvânt, Fiul lui Dumnezeu, este prezentat în trei epistole ${ }^{14}$ ca fiind în sens propriu Chipul lui Dumnezeu Tatăl (Col. 1, 13-15; Evr. 1, 3; II Cor. 4, 4). Pe Acest Cuvânt Îl trimite Dumnezeu Tatăl în lume ca semn al iubirii Sale de oameni (filantropia): „Căci Dumnezeu aşa a iubit lumea, încât pe Fiul Său Cel Unul-Născut L-a dat ca oricine crede în El să nu piară, ci să aibă viaţă veşnică” (In. 3, 16). Numai că această iubire pentru om nu este desemnată de textul grecesc prin filanthropia ${ }^{15}$, ci prin agape.

13 Gary B. Ferngren, Medicine \& Health Care in Early Christianity, Baltimore, The Johns Hopkins University Press, 2009, p. 97-98.

${ }^{14}$ J. BARR, Tertulian and the Unborn Child..., p. 83.

${ }^{15}$ De altfel, acest cuvânt este folosit doar de două ori în scrierile Noului Testament: Fapte 28, 2 și Tit 3, 4. Vezi: Mihai VIZITIU, Filantropia divină și filantropia Bisericii după Noul Testament, Iași, Edit. Trinitas, 2002, p. 14. 
Având în vedere aceste două aspecte ale imago Dei (omul - icoană a lui Dumnezeu-Treime și Hristos - Chipul lui Dumnezeu Celui nevăzut), nu este surprinzător ca interzicerea uciderii din Pentateuh (Ieș. 20, 13) să continue să fie un aspect fundamental al teologiei creștine. Evangheliile sinoptice l-au înfățișat pe Iisus Însuși enumerând omuciderea printre cele mai grave păcate (Mt. 5, 21; 15, 19; 19, 19; Mc. 10, 19; Lc. 18, 20). Faptul că Mesia creștinilor a condamnat direct și explicit actul suprimării vieții unui om, le-a oferit primilor creștini o autoritate clară pe care să-şi întemeieze interzicerea de a ucide. Începând cu Didahia, practica avortului va fi respinsă sub auspiciile acestui principiu ${ }^{16}$.

b) Fundamentarea interzicerii avortului și a expunerii nounăscuților se găsește în secțiunea dedicată căii morții. După cum putem anticipa, calea morții este văzută ca o respingere a filantropiei și iubirii și o acceptare a celor ce sunt ,în afară de Dumnezeu" ${ }^{17}$. Cei care îmbrățișează calea întunericului nu dau dovadă de compasiune faţă de cei săraci sau în situații de grea încercare, ci susțin mai degrabă interesele celor înstăriţi. Autorul blamează ucigașii copiilor în timp ce îi mustră pe cei care nu practică filantropia ${ }^{18}$.

Textul numește pe cei ce merg pe calea morții ,ignoranți ai Celui ce i-a creat, ucigași de copii, stricători ai zidirii lui Dumnezeu"19 (ov̉

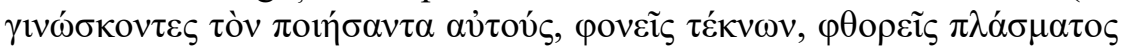
$\theta \varepsilon o \tilde{u})^{20}$. Originalul grecesc necesită câteva comentarii.

În primul rând, capitolul V al Didahiei poate fi privit în antiteză cu capitolele I-IV. Antiteza este folosită pentru a sublinia ,marea deosebire" ${ }^{21}$ dintre moralitatea cele două căi. Astfel se face că limbajul și structura tematică se păstrează, iar când vine vorba de ucidere, prin

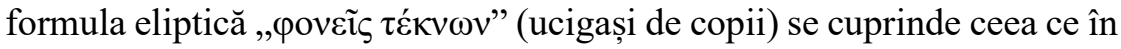

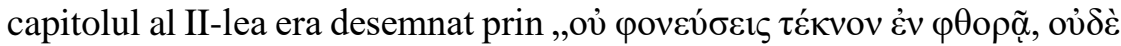
$\gamma \varepsilon v v \eta \theta \dot{\varepsilon} v \dot{\alpha} \pi 0 \kappa \tau \varepsilon v \varepsilon i \tilde{\zeta}$ " (nu veți ucide un copil prin avort și nici nu îl veți face să moară după naștere).

16 J. BARR, Tertulian and the Unborn Child..., p. 83.

${ }^{17}$ Didahia sau Învățătură a celor doisprezece Apostoli, V-VI, trad. cit., p. 28.

${ }^{18}$ Ibidem, V, 2, trad. cit., p. 28.

${ }_{19}$ Traducere proprie din greaca veche.

${ }^{20}$ The Teaching Of The Twelve Apostles, V, 2, trad. cit., p. 379.

${ }^{21}$ Didahia sau Învățătură a celor doisprezece Apostoli, I, 1, trad. cit., p. 25. 
În al doilea rând, traducerea românească sugerează că întregul paragraf din care face parte textul analizat poate fi așezat pe un fond biblic, întâlnit la proorocul Isaia, psalmistul David și în Înțelepciunea lui Solomon. Iată textele: „Fiii oamenilor, până când grei la inimă? Pentru ce iubiţi deşertăciunea şi căutaţi minciuna?” (Ps. 4, 2); „Mai-marii tăi sunt răzvrătiţi şi părtaşi cu hoţii; toţi iubesc darurile şi umblă după răsplată. Ei nu judecă orfanul, iar pricina văduvei nu ajunge până la ei” (Is. 1, 23); „Omorând fără milă pe prunci, mâncând carne omenească şi adăpându-se cu sânge; pe aceşti jertfitori spurcaţi și părinţi ucigaşi ai unor prunci fără de apărare ai voit să-i nimiceşti prin mâinile părinţilor noştri”" (Înţ. 12, 56). Pentru comparație redăm și textul Didahiei:

„prigonitori ai celor buni, urâtori de adevăr, iubitori de minciună; nu cunosc răsplata dreptății, nu se lipesc de bine, nici de dreapta judecată; nu priveghează spre bine, ci spre rău; bunătatea și răbdarea este departe de ei; iubesc cele deșarte, umblă după mită, nu miluiesc pe sărac, nu suferă pe cei necăjiți, nu cunosc pe Creatorul lor, ucigași de copii, stricători ai făpturii lui Dumnezeu, întorc spatele celui lipsit, asupresc pe cel în strâmtorare; apărători ai bogaților, judecători nelegiuiți ai săracilor, plini de tot păcatul. Izbăviţi-vă, fiilor, de toate acestea!"22.

În al treilea rând, ținând cont de acest fond biblic, putem analiza folosirea cuvântului „, $\lambda \lambda \alpha \dot{\sigma} \sigma \mu \alpha$, care desemnează un lucru modelat, plăsmuit de mână. Astfel, Septuaginta foloseşte acest cuvânt pentru a arăta că omul este o făptură zidită din țărână (Ps. 102, 1423); inima lui poate fi un $\dot{\alpha} \gamma \alpha \theta$ òv $\pi \lambda \dot{\alpha} \sigma \mu \alpha$ (Iudit. 8, 2924). Animalele sunt primele semne ale suveranității creatoare a lui Iahve $(\pi \lambda \alpha \dot{\sigma} \sigma \mu \alpha \tau o \varsigma)$ (Iov 40, 1925). , $\pi \lambda \alpha ́ \sigma \mu \alpha$ " este, de asemenea, utilizat pentru a desemna produsul olarului (Is. 29, 16 $\left.6^{26} ; 45,10\right)$, printre care și făurirea de idoli (Avac. 2, 18). Astfel, din utilizarea cuvântului , , $\lambda \lambda \alpha ́ \sigma \mu \alpha ”$ principalele idei teologice care se

${ }^{22}$ Ibidem, V, 2, trad. cit., p. 28.

${ }^{23}$ „Că El a cunoscut zidirea noastră, adusu-şi-a aminte că ţărână suntem”.

24 „Că nu de azi ți se cunoaște înțelepciunea, ci de la începutul zilelor tale poporul întreg ți-a cunoscut priceperea ca pe o bună alcătuire a inimii tale" (traducerea lui IPS Bartolomeu Anania).

25 „El [hipopotamul, n.n.] este fruntea făpturilor lui Dumnezeu şi făcut să fie cel mai mare peste celelalte dobitoace".

${ }^{26}$ „Ce stricăciune! Oare olarul poate fi socotit drept lut? Lucrul poate oare zice despre lucrător: «Nu m-a făcut el!» Vasul zice oare despre olar: «El nu pricepe?»». 
desprind sunt superioritatea Creatorului (Iov 40, 19; Is. 29, 16; 45, 10; Avac. 2,18) și îndurarea Lui față de oamenii care sunt plăsmuiți din țărână $($ Ps. 102, 14). Verbul derivat „, $\lambda \lambda \dot{\alpha} \sigma \sigma \omega ”$ (a modela, a plăsmui) este întrebuințat ca desemnând crearea omului de către Dumnezeu (Fac. 2, 7), dar și acțiunea de a alcătui în pântece o nouă viață umană, Autorul ei fiind tot Dumnezeu (Is. 49, 5²7 Ier. 1, 5). Noul Testament moștenește folosirea substantivului ca evocând activitatea olarului, care în cazul de faţă este Dumnezeu (Rom. 9, 20-21), iar verbul este folosit pentru a desemna zidirea lui Adam (I Tim. 2, 13).

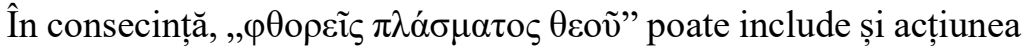

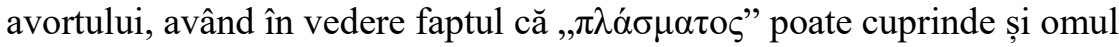
prenatal și omul postnatal. De remarcat este faptul că Didahia preia învățătura biblică conform căreia Autorul alcătuirii în pântece a copilului este Dumnezeu (Ps. 138, 13-16) și îi numește pe cei care atentează la viața umană, indiferent de stadiul ei, „stricători” ai rânduielii lui Dumnezeu.

În al patrulea rând, avortul este condamnat deoarece manifestă o uitare (sau chiar o revoltă) a omului față de starea lui de creatură. Didahia abordează de la rădăcină problema respectului pentru viață. Omul nu este propriul său creator, ci el este creat de Dumnezeu din dragoste, astfel încât ființa umană nu este stăpâna vieții sale sau a celorlalți (vezi Înț. 12, 5-6, care sintetizează învățătura Vechiului Testament în această privință $)^{28}$.

În al cincilea rând, textul despre uciderea prin avort este flancat de referiri la persoanele vulnerabile ale oricărei societăți, fie că vorbim de spațiu diferit sau de timp diferit: ,nu miluiesc pe sărac, nu suferă pe cei necăjiți”, urmează textul analizat, apoi fraza continuă cu ,întorc spatele celui lipsit, asupresc pe cel în strâmtorare". Nu știm cu certitudine care a fost intenția autorului, dar construcția frazei ne permite să îțtelegem o echivalență între nepăsarea, nepurtarea de grijă față de cei vulnerabili sau asuprirea lor (orfani, văduve, săraci, asupriți etc.) și uciderea prin avort sau abandonarea unui nou-născut. Echivalența aceasta intuiește că statutul de persoană vulnerabilă poate fi „conferit” atât orfanilor, săracilor, văduvelor, cât și copiilor nenăscuți sau abia născuți. Între aceste

27 „Domnul Cel Care $m$ - $a$ zidit din pântecele maicii mele ca să-i slujesc Lui şi să întorc pe Iacov către El şi să strâng la un loc pe Israel, căci aşa am fost eu cinstit în ochii Domnului şi Dumnezeul Meu fost-a puterea Mea".

${ }^{28}$ P. CASPAR, L'embryon au II ème siecle, p. 31. 
două categorii există o ,identitate de nevoie”, adică, din cauza statutului lor deosebit, nu se pot apăra și au cea mai mare nevoie de sprijinul și ajutorul oamenilor din jur ${ }^{29}$. Nu întâmplător teologia creștină a numit atât asuprirea orfanilor, văduvelor și săracilor, cât și omuciderea sau uciderea voită, păcate strigătoare la cer.

Epistola lui Barnaba a urmat aproape aceeași formă de argumentare ca Didahia cu privire la avort. Ea își structurează îndemnurile morale în funcție de învățătura celor două căi, a luminii și a întunericului. Autorul și-a îndemnat cititorii să se ferească de avort pe baza poruncii scripturistice: „,iubește-ți aproapele”: „Să nu te îndoiești dacă un lucru va fi sau nu. Să nu iei în deșert numele Domnului. Să iubești pe aproapele tău mai mult decât sufletul tău. Să nu ucizi copil în pântecele mamei și nici să-1 ucizi după ce s-a născut. Să nu-ți iei mâna ta de pe fiul tău sau de pe fiica ta, ci să-i înveți din tinerețe frica de Domnul"30.

$\mathrm{Cu}$ toate că formularea poruncii este foarte apropiată de cea din

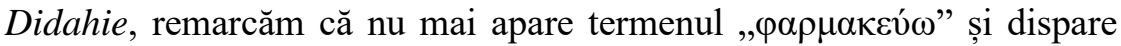
orice referire la practicile de eutanasiere. Ca și pasajul corespunzător din Didahie, este probabil ca acest text să vizeze toți participanții la un avort sau o expunere a nou-născuţilor, adică a membrilor familiei, a doctorilor și a moașelor ${ }^{31}$.

Autorul Epistolei a așezat avortul și infanticidul alături de opresiunea celor săraci și nevoiași. A prezentat copilul nenăscut ca un aproape, care are nevoie de binefacerea creștină ca orice alt membru al comunităţii aflat la nevoie. La fel ca în Didahia, autorul a legat ideile de infanticid și avort, dar niciodată nu a suștinut explicit că sunt sinonime. Didahia și Epistola lui Barnaba se aseamănă și în felul în care au legătură cu Decalogul, adică interzic în mod special avortul în termeni similari celor Zece Porunci. Ambii autori și-au presărat atenționările cu citate directe din Decalog, după cum se poate vedea și din citatul de mai sus. Este clar că autorii au dorit ca textele să fie în aceeași tradiție ca cele din cartea Ieșirea. În acest sens, interdicția împotriva avortului ar putea fi o

${ }^{29}$ Gheorghe PoPA, Introducere în Teologia Morală. Principii și concepte generale, Iași, Edit. Trinitas, 2003, p. 214.

${ }^{30}$ Epistola lui Barnaba, XIX, 5, trad. rom., note și indici de Dumitru Fecioru, în: P.S.B.

Vol. 1, București, EIBMBOR, 1979, p. 135.

${ }^{31}$ P. CASPAR, L'embryon au II ème siecle, p. 32. 
elaborare a poruncii Decalogului împotriva uciderii, ținând cont de discuția prezentă în Cartea Legământului despre pierderea unei sarcini în urma unei lovituri primite involuntar (Ieș. 21, 22-23) ${ }^{32}$.

Porunca este fundamentată, ca și în Didahie, pe ideea că cel care practică avortul sau expunerea nou-născuților neagă victimei sale realitatea că este făptură a lui Dumnezeu: este nerecunoscută stăpânirea lui Dumnezeu asupra destinului vieții umane ${ }^{33}$.

Mai poate fi amintit un text din Epistola către Diognet, care se referă doar la expunerea nou-născuților: „,[Creștinii] se căsătoresc ca toți oamenii și nasc copii, dar nu aruncă pe cei născuți. Întind masă comună, dar nu și patul. Sunt în trup, dar nu trăiesc după trup" ${ }^{34}$. Se poate observa intenția autorului de a arăta prin ce se deosebesc creștinii față de păgâni în ceea ce privește moralitatea sexuală și respectarea necondiționată a pruncilor nou-născuți.

\section{Concluzii}

1) Omul prenatal este un aproape aflat în cea mai plăpândă etapă a vieții sale. În limbajul de astăzi, acest lucru s-ar traduce prin faptul că embrionul sau fătul reprezintă un „cineva” căruia i se comunică dragostea, deci este o ființă umană distinctă și nu o anexă a trupului mamei, de care aceasta poate dispune în orice fel.

2) Copilul nenăscut este o persoană vulnerabilă, având o ,identitate de vulnerabilitate" cu orfanii, văduvele, săracii, asupriții etc. La fel cum suntem datori a ocroti pe sărmani și văduve, tot aşa trebuie să ocrotim și viața din pântece.

3) Interzicerea avortului este parte integrantă a unei etici creștine a nonviolenței și a iubirii.

4) Elementele identitare conturate în acest studiu sunt: embrionul este un aproape ce trebuie iubit; este o persoană vulnerabilă care nu se poate apăra; în toate stadiile sale de dezvoltare omul are aceeași valoare (principiul identității); Dumnezeu instituie o relație personală cu omul prenatal.

${ }^{32}$ Ideile paragrafului sunt sintetizate din: J. BARR, Tertulian and the Unborn Child..., p. 84.

${ }^{33}$ Epistola lui Barnaba, XX, 2, trad. cit., p. 136.

${ }^{34}$ Epistola către Diognet, V, 6-8, trad. rom., note și indici de Dumitru Fecioru, în: P.S.B. Vol. 1, Bucureşti, EIBMBOR, 1979, p. 340. 


\section{Referințe bibliografice:}

1. BARR, Julian, Tertulian and the Unborn Child. Christian and Pagan Attitudes in Historical Perspective, London and New York, Routledge, 2017;

2. CASPAR, Philippe, L'embryon au II ìme siecle, Paris, L'Harmattan, 2002;

3. Didahia sau Învăţătură a celor doisprezece Apostoli, trad. rom. de Dumitru Fecioru, în: P.S.B. Vol. 1, București, EIBMBOR, 1979;

4. Epistola către Diognet, trad. rom., note și indici de Dumitru Fecioru, în: P.S.B. Vol. 1, București, EIBMBOR, 1979;

5. Epistola lui Barnaba, trad. rom., note și indici de Dumitru Fecioru, în: P.S.B. Vol. 1, București, EIBMBOR, 1979;

6. FERngRen, Gary B., Medicine \& Health Care in Early Christianity, Baltimore, The Johns Hopkins University Press, 2009;

7. GRACIA, Diego, Fundamentos de bioética, Madrid, Editorial Triacastela, 2008;

8. KAPPARIS, Konstantinos, Abortion in the Ancient World, London, Duckworth Academic, 2002;

9. POPA, Gheorghe, Introducere în Teologia Morală. Principii și concepte generale, Iași, Edit. Trinitas, 2003;

10. The Teaching Of The Twelve Apostles, translation by Philip Schaff, coll. Ante-Nicene Fathers, vol. 7, Massachusetts, Hendrickson Publishers, 1995. 